\title{
ROLE OF PP2A IN INTRACELLULAR SIGNAL TRANSDUCTION PATHWAYS
}

\author{
Axel H. Schönthal
}

Department of Molecular Microbiology and Immunology, K. Norris Jr. Comprehensive Cancer Center, University of Southern California, 2011 Zonal Ave., HMR-405, Los Angeles, CA 90033

Received 8/25/98 Accepted 12/2/98

\section{TABLE OF CONTENTS}

\section{Abstract}

2. Introduction

3. Natural product inhibitors of phosphatases

4. Signal transduction pathways affected by okadaic acid

5. PP2A as a tumor suppressor

6. Experimentally increased $P P 2 A$ activity

7. Interaction of $P P 2 A$ with other regulatory proteins

8. Conclusions

9. References

\section{ABSTRACT}

Intracellular signal transduction pathways play a crucial role in a variety of cellular processes, such as differentiation, proliferation, or apoptosis, and the reversible phosphorylation of their components is a major regulatory mechanism to control their activities. While much has been learned about the contribution of kinases, the involvement of phosphatases in these events is less clear and has only recently received more investigative attention. The availability of various natural product inhibitors of phosphatases has helped enormously to gain insight into the role that these enzymes exert in various signal transduction processes. This review will focus on serine/threonine protein phosphatase type 2A (PP2A) and will present findings pertaining to its involvement in cellular signal transduction pathways. Since the majority of these studies were done with the use of phosphatase inhibitory compounds, some pros and cons of their application will be presented.

\section{INTRODUCTION}

Control of cellular growth and differentiation is a prerequisite for the proper development of higher eukaryotic organisms. Extracellular molecules, such as hormones or growth factors, are important agents in determining this control. The genetic response of cells to these molecules often requires signal receptors, signal transduction (second and third messengers), and usually alterations in the activity of transcription factors which activate or repress target genes. The importance of adequate regulation of these signal transduction pathways has been emphasized by the finding that many protein products of protooncogenes are components of this network. If mutated or inappropriately expressed, they become oncoproteins that are able to cause unrestricted cellular growth and carcinogenesis (1). 
Table 1. Inhibition of Phosphatases by Okadaic Acid Phosphatase $^{3} \quad$ IC50 (nM) References

\begin{tabular}{lll}
\hline PP1 & $20-100$ & $(11,13-15)$ \\
PP2A & $0.1-1.0$ & $(11,13,14)$ \\
PP2B & $>5000$ & $(16,17)$ \\
PP2C & no & $(16,17)$ \\
PP3 & $3.0-5.0$ & $(18)$ \\
PP4 & 0.2 & $(19)$ \\
PP5 & $<1.0$ & $(20)$ \\
PP6 & n.d. & $(21)$ \\
PP7 & no & $(22)$ \\
\hline
\end{tabular}

${ }^{\mathrm{T}}$ no inhibition, ${ }^{2}$ not determined, ${ }^{3}$ two novel type $2 \mathrm{C}$ protein phosphatases, wip1 and FIN13, are insensitive to okadaic acid $(23,24)$

Table 2. Inhibition of PP2A by Natural Product Inhibitors

\begin{tabular}{lll}
\hline Inhibitor & IC50 $(\mathbf{n M})$ & References \\
\hline Okadaic Acid & $0.02-2.0$ & $(11,14-16,30)$ \\
Calyculin A & $0.25-7.3$ & $(14-16,30)$ \\
Nodularin $^{1}$ & $0.03-1.0$ & $(14,31,32)$ \\
Microcystin-LR $^{1}$ & $0.04-2.0$ & $(14,33-35)$ \\
Tautomycin $^{\prime}$ & $10-23.1$ & $(14,33,36,37)$ \\
Fumonisin B1 & $3 \times 10^{5}$ & $(38)$ \\
Cantharidin $^{2}$ & 160 & $(39,40)$ \\
Thyrsiferyl $^{2}$ & $4-16 \times 10^{3}$ & $(41)$ \\
Motuporin $_{\text {Fostriecin }}$ & 0.1 & $(42)$ \\
Fon & $3.0-40$ & $(43,44)$
\end{tabular}

${ }^{\top}$ not cell permeable; liver cells appear to have an uptake system capable, of transporting this compound, ${ }^{2}$ Thyrsiferyl-23-acetate

phosphatases $\mathrm{CDC} 25 \mathrm{~A}$ and $\mathrm{CDC} 25 \mathrm{~B}$, which are able to transform cells in culture (7), and thus can be classified as oncogenes; the dual-specificity protein phosphatase PTEN (MMAC1) which is frequently found mutated or deleted in advanced cancers and behaves like a tumor suppressor gene (8). A further important regulator of signal transduction and cell growth is the serine/threonine protein phosphatase type 2A (PP2A) which will be discussed in detail below.

\section{NATURAL PRODUCT INHIBITORS OF PHOSPHATASES}

One compound that has proven to be extremely useful for the study of gene regulation by phosphatases is okadaic acid, a complex polyether derivative of a 38-carbon fatty acid. It is synthesized by marine dinoflagellates and accumulates in filter feeding organisms such as shellfish or the black sponge Halichondria okadaii from which it was first isolated $(9,10)$. Okadaic acid is a recognized threat to human health through its ability to cause diarrhetic shellfish poisoning. Its only cellular targets that could be identified so far are certain members of the serine/threonine protein phosphatase family, including PP2A (see table 1). Okadaic acid binds to the catalytic subunit and inhibits its enzymatic activity (11). Because of this specific repression of phosphatase activity, okadaic acid quickly became a ubiquitous tool to investigate the cellular functions of the respective okadaic acid-sensitive phosphatases (12).

Okadaic acid inhibits different phosphatases differentially, i.e. the concentration of the drug that inhibits phosphatase activity by $50 \%$ (IC50) varies greatly among the different members of this enzyme family (see table 1). Cellular effects that are observed in response to low concentrations of okadaic acid are often contributed to the inhibition of PP2A, as this particular phosphatase is inhibited at subnanomolar concentrations of the drug. However, this conclusion could be misleading, because there are other, less abundant phosphatases that are also affected by low okadaic acid concentrations, such as PP4 and PP5 (see table 1). Furthermore, PCR analysis indicated there are more phosphatases of this type yet to be discovered (25). Therefore, the cellular or molecular consequences of okadaic acid treatment, even at low concentrations, cannot be ascribed unequivocally to the inhibition of one particular phosphatase $(12,26)$.

In addition to okadaic acid, several other naturally occurring compounds have been found that are also able to inhibit phosphatase activity (see table 2). Although these inhibitors constitute a structurally diverse group of toxins that are produced by different organisms, computational analysis revealed that many of them possess similar threedimensional motifs that are involved in binding to the phosphatase catalytic subunit $(14,27,28)$. As is the case with okadaic acid, the inhibitory potency of the different compounds varies greatly among the different types of phosphatases. For example, the IC50 of tautomycin is approximately 10-fold higher for PP2A than for PP1, whereas the reverse is true for microcystin; fostriecin inhibits PP2A >10,000-fold more potently than PP1 (see refs. in table 2). Because of these differential effects, the combinatorial use of various phosphatase inhibitors may prove helpful to further narrow the list of candidate phosphatases that may be involved in the cellular processes under investigation (29).

It has to be kept in mind, however, that there is significant variation among the published IC50 values, which are dependent on the concentration of phosphatase as well as on the type of substrate used (17). Furthermore, these values are derived from measurements performed in vitro, i.e. by the use of cellular lysates or purified enzymes. To study the role of phosphatases in signal transduction pathways and gene regulation, these inhibitors need to be added to cells in culture. In this case, however, the efficient concentrations are significantly higher, and therefore the IC50 values do not reliably apply to these cell culture conditions. For instance, the published IC50 for okadaic acid is around $1 \mathrm{nM}$ with respect to PP2A activity in vitro (when added to diluted cellular lysate) $(11,15,30)$, whereas in cell culture (when added to growing cells) the IC50 was found to be $30 \mathrm{nM}$ and nearly 1 microM for NIH3T3 fibroblasts and MCF-7 breast cancer cells, respectively (45, 46).

Another caveat has to be considered when interpreting results obtained with the use of phosphatase inhibitors. It cannot be completely excluded that these 
compounds exhibit certain effects on cellular processes due to their potential interaction with yet unknown, nonphosphatase targets. Okadaic acid has been extensively studied, and no other cellular targets have been identified so far. However, some of the other phosphatase inhibitors do affect the activity of non-phosphatase proteins; most notably fostriecin, which inhibits partially purified type II topoisomerase, although at much higher concentrations (47).

Potential unknown targets of phosphatase inhibitors might contribute to the paradox that some of these compounds have tumor promoting activity, whereas others exhibit antitumor activity. Alternatively, or in addition, it may be of importance which combination of the various phosphatases is targeted by a certain inhibitor. Okadaic acid, calyculin A, microcystin-LR, and nodularin are potent tumor promoters or liver carcinogens (48-52), whereas tautomycin has not been found to promote tumors on mouse skin or rat glandular stomach (37). Moreover, fostriecin, cantharidin, and cantharidin derivatives have demonstrated antitumor properties (40, 53-55). Fostriecin in particular exhibits antitumor activity against a wide spectrum of tumor cells in vitro, and is under evaluation as an antitumor drug in clinical trials (56-58).

\section{SIGNAL TRANSDUCTION PATHWAYS AFFECTED BY OKADAIC ACID}

Originally, it was suspected that the tumor promoting activity of okadaic acid was due to its regulation of the same pathway that is affected by the well-established phorbol ester tumor promoters, namely the protein kinase $\mathrm{C}$ (PKC) pathway $(50,59,60)$. The idea was that activation of PKC by phorbol esters initiated a kinase cascade that lead to the increased phosphorylation/activation of various downstream components of this signal transduction pathway. Similarly, okadaic acid, through the inhibition of phosphatases that dephosphorylate/inactivate the same components, would generate the same net effect, namely the increased activity of this pathway. Further support for this hypothesis was provided by the finding that several growthregulatory genes that are activated by the phorbol ester 12O-tetradecanoyl-phorbol-13-acetate (TPA) are also activated by okadaic acid (see detailed references in (12)). Most prominent among these genes are the proto-oncogenes c-fos and c-jun (61-64), whose protein products are able to interact and form the heterodimeric transcription factor AP1 (65). And indeed, either agent, TPA or okadaic acid, causes increased AP-1 expression and activity (66-70). (For a detailed list of growth-regulatory genes that are regulated by okadaic acid, see ref. (71)). Activation of the c-fos gene is regulated through the reversible phosphorylation of ternary complex factor (TCF) by kinases of the mitogenactivated protein kinase (MAPK) family, and both agents, TPA and okadaic acid, stimulate TCF via the activation of the MAPK pathway (72). There are further examples of transcription factors that are activated by TPA and by okadaic acid. For example, the activity of nuclear factor kappa B (NF-kappaB) is stimulated by either agent $(73,74)$. Activation of NF-kappaB requires the degradation of protein inhibitors, IkappaB-alpha and IkappaB-beta, which is induced by the hyperphosphorylation of these proteins. It has been demonstrated that treatment of cells with okadaic acid or calyculin A results in the increased phosphorylation and subsequent degradation of these NF-kappaB inhibitors $(75,76)$. In the case of IkappaB-alpha, increased phosphorylation appears to be mediated through the (indirect) activation of ERK1, a member of the MAPK family, in response to okadaic acid treatment (76). Activation of the MAPK pathway by okadaic acid has been described by several groups (77-79).

However, while several cellular responses to drug treatment have been documented that are similar between okadaic acid and phorbol esters, there are also numerous differences. For example, using high definition twodimensional gel electrophoresis, Guy et al. (80) identified 74 proteins that exhibited altered levels of phosphorylation in response to okadaic acid treatment of human fibroblasts. However, when the same cells were treated with TPA, a rather different pattern of protein phosphorylation was found. Moreover, in other studies physiological differences between okadaic acid-generated and TPA-generated transformed cells have been reported $(61,81)$.

In addition, depending on the experimental approach, TPA and okadaic acid are able to antagonize each other's effects. For instance, it has been well documented that okadaic acid is able to induce apoptosis in various primary as well as transformed cells (82-85). In Balb/c 3T3 fibroblasts, this effect was found to be dependent on the presence of the p53 tumor suppressor protein (86), whereas in human breast carcinoma cells p53 function was not found to be required for this process (87). Further, in H-ras oncogene transformed cells okadaic acidinduced apoptosis appeared to involve the modulation of raf-1, PKC, and MAPK activities (88). Interestingly, the simultaneous treatment of certain breast cancer cell lines with okadaic acid and TPA has been shown to greatly diminish the induction of apoptosis by okadaic acid (89). Similarly, in THP-1 meyloid leukemia cells, cell death induced by okadaic acid is strongly reduced in the presence of TPA (90).

The various cellular responses to treatment with phosphatase inhibitors can differ enormously, and sometimes even yield contradicting results, which likely is due to variations in the length of treatment, the applied concentration, or the cell type used. In this regard, it was observed that okadaic acid, calyculin A, and cantharidin were able to prevent apoptosis in short term, but not in long term experiments (91). Similarly, the level of phosphorylation of the retinoblastoma $(\mathrm{Rb})$ tumor suppressor protein, an important regulator of cell cycle progression, is affected differentially by okadaic acid, depending on the time of incubation and concentration of the drug that is used (92-95). Moreover, several groups have reported okadaic acid as an inhibitor of transformation in different in vitro transformation assays $(96,97)$, which is in contrast to those reports discussed further above that established this compound as a potent tumor promoter. Whereas the details of these discrepancies remain to be investigated, the above data argue against the view that TPA 
and okadaic acid exert their effects through two sides of the same coin, i.e. the phosphorylation versus the inhibition of dephosphorylation of the same substrates of signal transduction pathways.

\section{PP2A AS A TUMOR SUPPRESSOR}

The finding that okadaic acid is a tumor promoter, combined with the observation that this compound efficiently inhibits PP2A, has led to the suggestion that PP2A, and potentially some other phosphatases, may function as tumor suppressors (60). It is thought that the tumor suppressing function could be accomplished by the enhanced dephosphorylation of activated kinase cascades, which would revert oncoprotein-activated signaling pathways back to their inactive state. As many oncogene products cause the sustained activation of growth-regulatory kinase cascades, it is a distinct possibility that increased serine/threonine protein phosphatase activity might counteract elevated levels of protein phosphorylation and block cellular transformation (48).

Further support for such a negative role of phosphatases in growth-regulatory signal transduction pathways came from observations that treatment of cells with okadaic acid led to the increased expression of several proto-oncogenes (see detailed references in (12)). Elevated expression of such genes had been shown before to contribute to cellular transformation (1). Thus, these results suggested that the respective okadaic acid sensitive phosphatases contribute to the repression of these protooncogenes in normal cells.

Moreover, when added to cells synchronized in the $\mathrm{S}$ phase of the cell cycle, okadaic acid caused an increase in the enzymatic activity of cyclin-dependent kinase (histone H1 kinase), an enzyme that is necessary for cell cycle progression. The drug also stimulated premature mitosis and increased the phosphorylation of mitosisspecific proteins (see detailed references in (12). When added at low concentrations, okadaic acid caused quiescent fibroblasts to progress to S phase of the cell cycle (98); and in thyroid cells, the drug increased the fraction of thyrotropin-stimulated quiescent cells entering $S$ phase (99). Further, a link between protein phosphatases and cellular transformation has been established by the finding that small DNA tumor viruses, such as Simian virus 40 (SV40) and Polyoma virus, synthesize proteins (small and medium $\mathrm{T}$ antigens) that bind to and inhibit PP2A (100). The currently available evidence indicates that alteration of phosphatase activity and subsequent changes in phosphorylation levels is a crucial step in transformation by these viruses $(55,100)$. Another viral protein, E4orf4 of Adenovirus, has been found to associate with PP2A as well (101).

Further evidence for the involvement of phosphatases in the neoplastic process has been provided by the finding that certain cis-platin resistant human cancer cells are resistant to growth inhibition by okadaic acid, and exhibit increased phosphorylation of certain nuclear proteins (102, 103). Resistance to okadaic acid has also been observed in cells that exhibit the multidrug resistance (mdr) phenotype (104-108). Mdr cells were established by chronic exposure of cells to increasing concentrations of okadaic acid. In this case, two different mechanisms were found to generate the mdr phenotype.

First, mdr cells had amplified the gene encoding the $170-\mathrm{kDa}$ P-glycoprotein, which is a drug efflux pump with broad specificity, i.e. it is capable of extruding intracellular anticancer agents of diverse structures and mechanisms of action $(105,106)$. Consequently, these cells were not only resistant to okadaic acid and related phosphatase-inhibitory compounds, but also to other structurally unrelated anticancer drugs, such as vinblastine, taxol, or cisplatin. In addition, the activity of P-glycoprotein appears to be regulated via its phosphorylation status, which is increased in response to treatment of cells with okadaic (109). It should be noted, however, that the increased activity of the P-glycoprotein pump could not be demonstrated in all okadaic acid resistant cell types; in some cells no differences could be found in the accumulation or efflux of okadaic acid between drug resistant and normal cells $(104,107,110)$.

A second mechanism that was found to generate okadaic acid resistant cell lines is the mutational alteration of the PP2A catalytic subunit. Upon sequencing of the PP2A gene from okadaic acid resistant hamster cells, a point mutation was found that resulted in the exchange of cysteine 269 for glycine (111). This mutation resulted in a PP2A protein that was much more resistant to inhibition by okadaic acid than the wild type protein. Further mutational analysis of this region established that the amino acids 265 to 269 are critical for inhibition of PP2A by okadaic acid (112). Mdr cell lines that harbored such a mutation of PP2A were found to express the mdr phenotype in a stable fashion. In contrast, cell lines without PP2A mutations but with amplified P-glycoprotein, tended to loose the $\mathrm{mdr}$ phenotype after cessation of long-term drug exposure (110).

In addition to gene amplification, the treatment of cells with okadaic acid has also generated other genetic changes in cultured cells, such as mutations endowing diphtheria-toxin resistance, sister chromatid exchange in the presence of bromodeoxyuridine, loss of exogenous transforming oncogenes, and minisatellite mutations (26, 113-116). Although the molecular mechanisms underlying this genotoxic activity of okadaic acid have not been elucidated, it is suspected that the alteration of the phosphorylation status of cellular proteins, and the resulting changes in the gene expression pattern, might be a crucial epigenetic event contributing to these processes. In this regard, it is important to note that okadaic acid induces elevated and sustained expression of the c-fos protooncogene $(63,105)$. Since c-fos has been shown to increase the spontaneous level of chromosomal aberrations (117119), it is conceivable that okadaic acid may stimulate these processes through its continuous activation of c-fos expression. Furthermore, since okadaic acid exerts its effect on c-fos expression through inhibition of PP2A $(120,121)$, one could envision that PP2A, through its negative effects on the c-fos gene, may contribute to the maintenance of genomic integrity. Thus, these observations give further 
credence to the idea that PP2A indeed may act as a tumor suppressor.

\section{EXPERIMENTALLY INCREASED PP2A ACTIVITY}

The down-regulation of phosphatase activity by the use of various natural product inhibitors has yielded lots of preliminary insight into phosphatase function, although this approach has been rather restricted due to the simultaneous effects on several different enzymes (see further above). A different avenue has been pursued with the use of the small tumor (T) antigens of polyomavirus or SV40. These proteins have been found to form stable complexes with PP2A and reduce its enzymatic activity (55, $100,122)$, and therefore have served as rather specific tools to analyze in more detail the involvement of PP2A in signal transduction pathways. For example, introducing SV40 small $\mathrm{T}$ antigen into cells has helped establish a negative role for PP2A in the regulation of the mitogen activated protein (MAP) kinase pathway $(78,123)$. (The details of these interactions will be discussed elsewhere in this volume and thus will not be pursued here.)

The opposite experimental approach, the stably increased expression of selected protein phosphatases, would also be helpful to further study their role in signal transduction pathways. However, these types of studies have proven difficult to accomplish. Although it has been shown in mammalian cells that PP2A can be efficiently expressed after transfection of an expression vector containing the cDNA of the catalytic subunit of PP2A (124), there appears to be a potent autoregulatory mechanisms that keeps the overall amount of PP2A protein (catalytic subunit), as well as its enzymatic activity, at constant levels (125). As a consequence, it seems very difficult to establish cell lines with significantly increased overall activity of PP2A.

The observed autoregulatory control of PP2A expression may also provide an explanation for earlier seemingly contradictory findings by others who investigated PP2A expression. For example, in various mammalian cells and in fission yeast it has been shown that the level of PP2A protein remains constant throughout the cell cycle (126128). In contrast, analyzing the amount of mRNA, others have demonstrated increased PP2A mRNA levels during the early stages of G1 in mammalian cells $(129,130)$. Moreover, Kakinoki et al. (131), by performing partial hepatectomy, presented evidence of almost constant levels of PP2A protein in regenerating liver, despite a 30 -fold increase in PP2A mRNA. These observed discrepancies between elevated mRNA levels and rather constant protein levels can now be explained by the finding of a potent autoregulatory mechanism of PP2A synthesis that appears to work at the level of translation (125). In addition, in human keratinocytes a post-translational level of PP2A regulation was suggested (132).

In order to neutralize and overcome the autoregulatory feedback loop of PP2A expression, different experimental approaches may be useful. For example, microinjection studies have been used to introduce into cells various components of the phosphatase holoenzyme (121, 133). It is likely that in these experiments the large amount of microinjected protein is able to overwhelm any autoregulatory mechanism, at least for a short time, and induce the respective cellular responses. Experiments of this type, although limited by the small number of cells that can be used per experiment, have indeed provided valuable insights into phosphatase function $(121,134-136)$.

A further strategy to manipulate PP2A activity in cells was recently presented by Ruediger et al. (137). These authors generated an $\mathrm{N}$-terminal mutant of the regulatory A subunit that was able to bind to the catalytic $\mathrm{C}$ subunit, but not to the regulatory B subunit. Expression of this A subunit mutant in cells resulted in an increase in the amount of PP2A core protein (A-C heterodimers) and a decrease in the amount of PP2A holoenzyme (B-A-C heterotrimers). Concomitantly, the relative activity of PP2A towards two different substrates, phosphorylase-a and a retinoblastoma $(\mathrm{Rb})$ peptide, was altered. In the case of phosphorylase-a, PP2A activity was slightly stimulated, whereas with Rb peptide a significant inhibition of phosphatase activity was obtained (137). This differential effect of PP2A enzymatic activity generated consequences at the molecular and cellular level as well: transcription from the human immunodeficiency virus (HIV-1) long terminal repeat (LTR), as well as virus production, was inhibited in these cells (137). Thus, these results demonstrated that the manipulation of PP2A subunits, other than the catalytic C subunit, may be a useful experimental approach to manipulate PP2A expression and activity in living cells.

\section{INTERACTION OF PP2A WITH OTHER REGULATORY PROTEINS}

The involvement of PP2A in intracellular signal transduction pathways can be inferred most directly from experiments that establish the interaction of this enzyme with other cellular regulatory components. For example, most recently it was found that the trimeric PP2A holoenzyme can form a stable complex with $\mathrm{Ca}^{2+}$ - calmodulin-dependent kinase IV (CaMKIV) (138). In this interaction, PP2A serves to ensure the transient nature of CaMKIV activation: after the kinase has phosphorylated its substrates, CaMKIV activity is down-regulated by PP2A. Thus, this association of a phosphatase with a kinase, where PP2A functions as the negative regulator of CaMKIV, allows tight control of the corresponding signal transduction pathway.

In other studies, PP2A has been shown to interact with casein kinase 2alpha (CK2alpha) in mitogen starved cells (139). CK2alpha was found to negatively regulate the activity of the mitogen-activated protein kinase (MAPK) pathway. This inhibition appears to be mediated through the phosphorylation/activation of PP2A by CK2alpha, and the subsequent dephosphorylation/deactivation of MAPK kinase (MEK) by PP2A $(78,139)$. Because the MAPK pathway is one of the major growth regulatory pathways, these findings provide yet another example of the apparently crucial role of PP2A in cellular growth control. 
Several other cellular signaling proteins have been identified that interact with PP2A (140-142). Notably HOX11, a homeo box gene product which is able to transform cells, associates with the catalytic subunit of PP2A (143). This interaction is thought to affect alterations of cell cycle progression induced by HOX11. In other studies, the translation termination factor eRF1 (eukaryotic release factor 1) has been found complexed with PP2A, which may serve to bring the phosphatase into contact with putative targets among the components of the translational apparatus (144).

In addition, the recruitment of PP2A to signal transduction pathways and other regulatory events may be regulated through its B-type subunits, which may add yet another layer of control and specificity. In this regard, it has been found that the B'alpha and the B'beta subunits of PP2A form complexes with cyclin $\mathrm{G}$, a protein whose expression is regulated by the tumor suppressor p53 (145). Because induction of $\mathrm{p} 53$ protein appears to be required for this complex formation, the existence of specific cross-talk between PP2A and p53-mediated pathways has been suggested (145).

\section{CONCLUSIONS}

Great strides have been made towards a more complete understanding of phosphatase function in cellular signal transduction. However, because in most studies okadaic acid or other phosphatase inhibitors were used, it was often not possible to unequivocally establish which of the various drug-sensitive phosphatases was responsible for the observed effects. Rather, a combination of various approaches is necessary in order to characterize the precise roles of phosphatases in signal transduction pathways. For example, biochemical and immunological analysis together with cellular studies may be most useful. Moreover, the recent discoveries of complexes consisting of a kinase and a phosphatase suggest a tight coupling of activators with their respective inactivator; thus, the analysis of this type of interaction may lead the way to further unravel the contribution of various phosphatases to the regulation of cellular signal transduction pathways.

\section{REFERENCES}

1. Cooper, G. M.: Oncogenes. Boston, MA: Jones and Barlett (1990)

2. Hunter, T.: Protein kinases and phosphatases: the Yin and Yang of protein phosphorylation and signaling. Cell 80, 225-236 (1995)

3. Heldin, C.-H. \& M. Purton: Signal Transduction. In: R. Bradshaw and M. Purton (eds.), Modular Texts in Molecular and Cell Biology 1. London: Chapman \& Hall (1996)

4. Jones, C. L. A. \& M. A. Kane: Oncogenic signaling. Curr. Opin. Oncol. 8, 54-59 (1996)

5. Broach, J. R. \& A. J. Levine: Oncogenes and cell proliferation. Curr. Opin. Genetics Devel. 7, 1-113 (1997)
6. Parsons, R.: Phosphatases and tumorigenesis. Curr. Opin. Oncol. 10, 88-91 (1998)

7. Galaktionov, K., A. K. Lee, J. Ekstein, G. Draetta, J. Meckler, M. Loda \& D. Beach: CDC25 phosphatases as potential human oncogenes. Science 269, 1575-1577 (1995)

8. Myers, M. P. \& N. K. Tonks: PTEN: Sometimes taking it off can be better than putting it on. Am. J. Hum. Genet. 61, 1234-1238 (1997)

9. Murakami, Y., Y. Oshima \& T. Yasumoto: Identification of okadaic acid as a toxic component of marine dinoflagellate. Bull. Jap. Soc. Sci. Fish. 48, 69-72 (1982)

10. Tachibana, K., P. J. Scheuer, Y. Tsukitani, H. Kikuchi, D. Van Engen, J. Clardy, Y. Gopichand \& F. J. Schmitz: Okadaic acid, a cytotoxic polyether from two marine sponges of the genus Halichondria. J. Am. Chem. Soc. 103, 2469-2471 (1981)

11. Bialojan, C. \& A. Takai: Inhibitory effect of a marine sponge toxin, okadaic acid, on protein phosphatases. Biochem. J. 256, 283-290 (1988)

12. Schönthal, A.: Okadaic acid: A valuable new tool to study signal transduction and cell cycle regulation? New Biologist 4, 16-21 (1992)

13. Cohen, P. T. W., M. X. Chen \& C. G. Armstrong: Novel protein phosphatases that may participate in cell signaling. In: H. Hidaka and A. C. Nairn (eds.), Advances in Pharmacology: Intracellular Signal Transduction, Vol. 36, pp. 67-89. Boston: Academic Press (1996)

14. Gupta, V., A. K. Ogawa, X. Du, K. N. Houk \& R. W. Armstrong: A model for binding of structurally diverse natural product inhibitors of protein phosphatases PP1 and PP2A. J. Medic. Chem. 40, 3199-3206 (1997)

15. Ishihara, H., B. L. Martin, D. L. Brautigan, H. Karaki, H. Ozaki, Y. Kato, N. Fusetani, S. Watabe, K. Hashimoto \& D. Uemura: Calyculin A and okadaic acid: Inhibitors of protein phosphatase activity. Biochem. Biophys. Res. Comm. 159, 871-877 (1989)

16. Cohen, P.: The structure and regulation of protein phosphatases. Ann. Rev. Biochem. 58, 453-508 (1989)

17. Cohen, P.: Classification of protein serine/threonine phosphatases: Identification and quantitation in cell extracts. In: T. Hunter and B. M. Sefton (eds.), Methods in Enzymology: Protein Phosphorylation, Part B, Vol. 201. San Diego: Academic Press (1991)

18. Honkanen, R. E., J. Zwiller, S. L. Daily, B. S. Khatra, M. Dukelow \& A. L. Boynton: Identification, purification, and characterization of a novel serine/threonine protein phosphatase from bovine brain. J. Biol. Chem. 266, 66146619 (1991)

19. Brewis, N. D., A. J. Street, A. R. Prescott \& P. T. W. Cohen: PPX, a novel protein serine/threonine phosphatase localized to centrosomes. EMBO J. 12, 987-996 (1993)

20. Chen, M. X., A. E. McPartlin, L. Brown, Y. H. Chen, H. M. Barker \& P. T. W. Cohen: A novel human protein 
serine/threonine phosphatase, which possesses four tetratricopeptide repeat motifs and localizes to the nucleus. EMBO J. 13, 4278-4290 (1994)

21. Bastians, H. \& H. Ponstingl: The novel human protein serine/threonine phosphatase 6 is a functional homologue of budding yeast Sit $4 p$ and fission yeast ppe1, which are involved in cell cycle regulation. J. Cell Sci. 109, 2865-2874 (1996)

22. Huang, X. \& R. E. Honkanen: Molecular cloning, expression, and characterization of a novel human serine/threonine protein phosphatase, PP7, that is homologous to Drosophila retinal degeneration $\mathrm{C}$ gene product (rdgC). J. Biol. Chem. 273, 1462-1468 (1998)

23. Fiscella, M., H. Zhang, S. Fan, K. Sakaguchi, S. Shen, W. E. Mercer, G. F. Vande Woude, P. M. O'Connor \& E. Appella: Wip1, a novel human protein phosphatase that is induced in response to ionizing radiation in a p53-dependent manner. Proc. Natl. Acad. Sci. USA 94, 6048-6058 (1997)

24. Guthridge, M. A., P. Bellosta, N. Tavoloni \& C. Basilico: FIN13, a novel growth factor-inducible serinethreonine phosphatase which can inhibit cell cycle progression. Mol. Cell. Biol. 17, 5485-5498 (1997)

25. Chen, M. X., Y. H. Chen \& P. T. W. Cohen: Polymerase chain reactions using Saccharomyces, Drosophila and human DNA predict a larger family of protein serine/threonine phosphatases. FEBS L. 306, 54-58 (1992)

26. Nagao, M., H. Shima, M. Nakayasu \& T. Sugimura: Protein serine/threonine phosphatases as binding proteins for okadaic acid. Mutation Res. 333, 173-179 (1995)

27. Bagu, J. R., B. D. Sykes, M. M. Craig \& C. F. Holmes: A molecular basis for different interactions of marine toxins with protein phosphatase-1. Molecular models for bound motuporin, microcystins, okadaic acid, and calyculin A. $J$. Biol. Chem. 272, 5087-5097 (1997)

28. Gauss, C. M., J. E. Sheppeck, A. C. Nairn \& R. Chamberlin: A molecular modeling analysis of the binding interactions between the okadaic acid class of natural product inhibitors and the Ser-Thr phosphatases, PP1 and PP2A. Bioorg. Med. Chem. 5, 1751-1773 (1997)

29. Schönthal, A. H.: Analyzing gene expression with the use of serine/threonine phosphatase inhibitors. In: J. W. Ludlow (ed.) Methods in Molecular Biology: Protein Phosphatase Protocols, Vol. 93, pp. 35-40. Totowa, N.J.: Humana Press (1998)

30. Cohen, P., S. Klumpp \& D. L. Schelling: An improved procedure for identifying and quantitating protein phosphatases in mammalian tissues. FEBS L. 250, 596-600 (1989)

31. Honkanen, R. E., B. A. Codispoti, K. Tse \& A. L. Boynton: Characterization of natural toxins with inhibitory activity against serine/threonine protein phosphatases. Toxicon 32, 339-350 (1994)
32. Honkanen, R. E., M. Dukelow, J. Zwiller, R. E. Moore, B. S. Khatra \& A. L. Boynton: Cyanobacterial nodularin is a potent inhibitor of type 1 and type 2 A protein phosphatases. Mol. Pharmacol. 40, 577-583 (1991)

33. Takai, A., K. Sasaki, H. Nagai, G. Mieskes, M. Isobe, K. Isono \& T. Yasumoto: Inhibition of specific binding of okadaic acid to protein phosphatase $2 \mathrm{~A}$ by microcystin-LR, calyculin A and tautomycin. Biochem. J. 306, 657-665 (1995)

34. MacKintosh, C., K. A. Beattie, S. Klumpp, P. Cohen \& G. A. Codd: Cyanobacterial microcystin-LR is a potent and specific inhibitor of protein phosphatases 1 and $2 \mathrm{~A}$ from both mammals and higher plants. Fed. Eur. Biochem. Soc. Lett. 264, 187-192 (1990)

35. Honkanen, R. E., J. Zwiller, R. E. Moore, S. L. Daily, B. S. Khatra, M. Dukelow \& A. L. Boynton: Characterization of microcystin-LR, a potent inhibitor of type 1 and type 2A protein phosphatases. J. Biol. Chem. 265, 19401-19404 (1990)

36. MacKintosh, C. \& S. Klumpp: Tautomycin from the bacterium Streptomyces verticillatus, another potent and specific inhibitor of protein phosphatases. FEBS L. 277, 137-140 (1990)

37. Suganuma, M., S. Okabe, E. Sueoka, R. Nishiwaki, A. Komori, N. Uda, K. Isono \& H. Fujiki: Tautomycin: an inhibitor of protein phosphatases 1 and 2A but not a tumor promoter on mouse skin and in rat glandular stomach. $J$. Cancer Res. Clin. Oncol. 121, 621-627 (1995)

38. Fukuda, H., H. Shima, R. F. Vesonder, H. Tokuda, H. Nishio, S. Katoh, S. Tamura, T. Sugimura \& M. Nagao: Inhibition of protein serine/threonine phosphatases by fumonisin B1, a mycotoxin. Biochem. Biophys. Res. Comm. $220,160-165$ (1996)

39. Li, Y. M. \& J. E. Casida: Cantharidin-binding protein: identification as protein phosphatase 2A. Proc. Nat. Acad. Sci. USA 89, 11867-11870 (1992)

40. Honkanen, R. E.: Cantharidin, another natural toxin that inhibits the activity of serine/threonine protein phosphatases types 1 and 2A. Fed. Eur. Biochem. Soc. Lett. 330, 283286 (1993)

41. Matsuzawa, S., T. Suzuki, M. Suzuki, A. Matsuda, T. Kawamura, Y. Mizuno \& K. Kikuchi: Thyrsiferyl 23-acetate is a novel specific inhibitor of protein phosphatase PP2A. Fed. Eur. Biochem. Soc. Lett. 356, 272-274 (1994)

42. Craig, M., H. A. Luu, T. L. McCready, D. Williams, R. J. Anderson \& C. F. Holmes: Molecular mechanisms underlying he interaction of motuporin and microcystins with type-1 and type-2A protein phosphatases. Biochem. Cell Biol. 74, 569-578 (1996)

43. Roberge, M., C. Tudan, S. M. Hung, K. W. Harder, F. R. Jirik \& H. Anderson: Antitumor drug fostriecin inhibits the mitotic entry checkpoint and protein phosphatases 1 and 2A. Cancer Res. 54, 6115-6121 (1994) 
44. Walsh, A. H., A. Cheng \& R. E. Honkanen: Fostriecin, an antitumor antibiotic with inhibitory activity against serine/threonine protein phosphatases types 1 (PP1) and 2A (PP2A), is highly selective for PP2A. Fed. Eur. Biochem. Soc. Lett. 416, 230-234 (1997)

45. Favre, B., P. Turowski \& B. A. Hemmings: Differential inhibition and posttranslational modification of protein phosphatase 1 and 2A in MCF7 cells treated with calyculinA, okadaic acid, and tautomycin. J. Biol. Chem. 272, 13856-13863 (1997)

46. Jaramillo-Babb, V., J. L. Sugarman, R. Scavetta, S.-J. Wang, N. Berndt, T. L. Born, C. K. Glass \& A. H. Schönthal: Positive regulation of cdc2 gene activity by protein phosphatase type 2A. J. Biol. Chem. 271, 59885992 (1996)

47. Boritzki, T. J., T. S. Wolfard, J. A. Besserer, R. C. Jackson \& D. W. Fry: Inhibition of type II topoisomerase by fostriecin. Biochem. Pharmacol. 37, 4063-4068 (1988)

48. Fujiki, H. \& M. Suganuma: Tumor promotion by inhibitors of protein phosphatases 1 and 2A: the okadaic acid class of compounds. Adv. Cancer Res. 61, 143-194 (1993)

49. Ohta, T., E. Sueoka, N. Iida, A. Komori, M. Suganuma, R. Nishiwaki, M. Tatematsu, S. J. Kim, W. W. Carmichael \& H. Fujiki: Nodularin, a potent inhibitor of protein phosphatases 1 and 2A, is a new environmental carcinogen in male F344 rat liver. Cancer Res. 54, 6402-6406 (1994)

50. Suganuma, M., H. Fujiki, H. Suguri, S. Yoshizawa, M. Hirota, M. Nakayasu, M. Ojika, K. Wakamatsu \& K. Yamada: Okadaic acid: an additional non-phorbol-12tetradecanoate-13-acetate-type tumor promoter. Proc. Nat. Acad. Sci. USA 85, 1768-1771 (1988)

51. Yoshizawa, S., R. Matsushima, M. F. Watanabe, K. Harada, A. Ichihara, W. W. Carmichael \& H. Fujiki: Inhibition of protein phosphatases by microcystins and nodularin associated with hepatotoxicity. J. Cancer Res. Clin. Oncol. 116, 609-614 (1990)

52. Suganuma, M., H. Fujiki, H. Furuya-Suguri, S. Yoshizawa, S. Yasumoto, Y. Kato, N. Fusetani \& T. Sugimura: Calyculin A, an inhibitor of protein phosphatases, a potent tumor promoter on CD-1 mouse skin. Cancer Res. 50, 3521-3525 (1990)

53. Liu, X. H., I. Blazsek, M. Comisso, S. Legras, S. Marion, P. Quittet, A. Anjo, G. S. Wang \& J. L. Misset: Effects of norcantharidin, a protein phosphatase type-2A inhibitor, on the growth or normal and malignant haemopoietic cells. European Journal of Cancer 31A, 953963 (1995)

54. Walter, W. G.: Antitumor imide derivatives of 7oxabicyclo[2.2.1]heptane-2,3-dimethyl-2,3-dicarboxylic acid. J. Pharm. Sci. 78, 66-67 (1989)

55. Walter, G. \& M. Mumby: Protein serine/threonine phosphatases and cell transformation. Biochim. Biophys. Acta 1155, 207-226 (1993)
56. Leopold, W. R., J. L. Shillis, A. E. Mertus, J. M. Nelson, B. J. Roberts \& R. C. Jackson: Anticancer activity of the structurally novel antibiotic Cl-920 and its analogues. Cancer Res. 44, 1928-1932 (1984)

57. de Jong, R. S., E. G. De Vries \& N. H. Mulder: Fostriecin: a review of the preclinical data. Anticancer Drugs 8, 413-418 (1997)

58. Scheithauer, W., D. D. Von Hoff, G. M. Clark, J. L. Shillis \& E. F. Elslager: In vitro activity of the novel antitumor antibiotic fostriecin (Cl-920) in a human tumor cloning assay. Eur. J. Cancer Clin. Oncol. 22, 921-926 (1986)

59. Sassa, T., W. W. Richter, N. Uda, M. Suganuma, H. Suguri, S. Yoshizawa, M. Hirota \& H. Fujiki: Apparent "activation" of protein kinases by okadaic acid class tumor promoters. Biochem. Biophys. Res. Comm. 159, 939-944 (1989)

60. Cohen, P. \& P. T. W. Cohen: Protein phosphatases come of age. J. Biol. Chem. 264, 21435-21438 (1989)

61. Herschman, H. R., R. W. Lim, D. W. Brankow \& H. Fujiki: The tumor promoters 12-O-tetradecanoylphorbol-13acetate and okadaic acid differ in toxicity, mitogenic activity and induction of gene expression. Carcinogenesis 10, 14951498 (1989)

62. Kim, S. J., R. Lafyatis, K. Y. Kim, P. Angel, H. Fujiki, M. Karin, M. B. Sporn \& A. B. Roberts: Regulation of collagenase gene expression by okadaic acid, an inhibitor of protein phosphatases. Cell Regulation 1, 269-278 (1990)

63. Schönthal, A., Y. Tsukitani \& J. R. Feramisco: Transcriptional and post-transcriptional regulation of c-fos expression by the tumor promoter okadaic acid. Oncogene 6, 423-430 (1991)

64. Schönthal, A., A. S. Alberts, J. A. Frost \& J. R. Feramisco: Differential regulation of jun family gene expression by the tumor promoter okadaic acid. New Biologist 3, 977-986 (1991)

65. Lee, W., P. Mitchell \& R. Tjian: Purified transcription factor AP-1 interacts with TPA-inducible enhancer elements. Cell 49, 741-752 (1987)

66. Angel, P., M. Imagawa, R. Chiu, B. Stein, R. J. Imbra, H. J. Rahmsdorf, C. Jonat, P. Herrlich \& M. Karin: Phorbol ester-inducible genes contain a common cis element recognized by a TPA-modulated trans-acting factor. Cell 49, 729-739 (1987)

67. Haby, C., D. Aunis \& J. Zwiller: Okadaic acid induces activator protein 1 activity and immediate early gene transcription in rat pheochromocytoma cells. Mechanism of action. Biochem. Pharmacol. 48, 819-825 (1994)

68. Peng, J., G. T. Bowden \& F. E. Domann: Activation of AP-1 by okadaic acid in mouse keratinocytes associated with hyperphosphorylation of c-jun. Mol. Carcinogenesis 18, 37-43 (1997) 
69. Rosenberger, S. F. \& G. T. Bowden: Okadaic acid stimulated TRE binding activity in a papilloma producing mouse keratinocyte cell line involves increased AP-1 expression. Oncogene 12, 2301-2308 (1996)

70. Thévenin, C., S. J. Kim \& J. H. Kehrl: Inhibition of protein phosphatases by okadaic acid induces AP1 in human T cells. J. Biol. Chem. 266, 9363-9366 (1991)

71. Schönthal, A. H.: Regulation of gene expression by serine/threonine protein phosphatases. Sem. Cancer Biol. 6, 239-248 (1995)

72. Hipskind, R. A., M. Baccarini \& A. Nordheim: Transient activation of RAF-1, MEK, and ERK2 coincides kinetically with ternary complex factor phosphorylation and immediate-early gene promoter activity in vivo. Mol. Cell. Biol. 14, 6219-6231 (1994)

73. Thévenin, C., S. J. Kim, P. Rieckmann, H. Fujiki, M. A. Norcross, M. B. Sporn, A. S. Fauci \& J. H. Kehrl: Induction of nuclear factor-kappa B and the human immunodeficiency virus long terminal repeat by okadaic acid, a specific inhibitor of phosphatases 1 and 2A. New Biologist 2, 793-800 (1990)

74. Baumann, B., B. Kistler, A. Kirillov, Y. Bergman \& T. Wirth: The mutant plasmacytoma cell line S107 allows the identification of distinct pathways leading to NF-kappaB activation. J. Biol. Chem. 273, 11448-11455 (1998)

75. Harhaj, E. W. \& S. C. Sun: The serine/threonine phosphatase inhibitor calyculin A induces rapid degradation of IkappaBbeta. Requirement of both the N- and C-terminal sequences. J. Biol. Chem. 272, 5409-5412 (1997)

76. Sonoda, Y., T. Kasahara, Y. Yamaguchi, K. Kuno, K. Matsushima \& N. Mukaida: Stimulation of interleukin-8 production by okadaic acid and vanadate in a human promyelocyte cell line, and HL-60 subline. Possible role of mitogen-activated protein kinase on the okadaic acidinduced NF-kappaB activation. J. Biol. Chem. 272, 1536615372 (1997)

77. Braconi Quintaje, S. B., D. J. Church, M. Rebsamen, M. B. Valloton, B. A. Hemmings \& U. Lang: Role of protein phosphatase $2 \mathrm{~A}$ in the regulation of mitogen-activated protein kinase activity in ventricular cardiomyocytes. Biochem. Biophys. Res. Comm. 221, 539-547 (1996)

78. Sontag, E., S. Fedorov, C. Kamibayashi, D. Robbins, M. Cobb \& M. Mumby: The interaction of SV40 small tumor antigen with protein phosphatase 2A stimulates the MAP kinase pathway and induces cell proliferation. Cell 75, 887-897 (1993)

79. Sontag, E., J. M. Sontag \& A. Garcia: Protein phosphatase $2 \mathrm{~A}$ is a critical regulator of protein kinase $\mathrm{C}$ zeta signaling targeted by SV40 small t to promote cell growth and NF-kappaB activation. EMBO J. 16, 5662-5671 (1997)

80. Guy, G. R., X. Cao, S. P. Chua \& Y. H. Tan: Okadaic acid mimics multiple changes in early protein phosphorylation and gene expression induced by tumor necrosis factor or interleukin-1. J. Biol. Chem. 267, 18461852 (1992)

81. Katoh, F., D. J. Fitzgerald, L. Giroldi, H. Fujiki, T. Suginuma \& H. Yamasaki: Okadaic acid and phorbol esters: comparative effects of these tumor promoters on cell transformation, intercellular communication and differentiation in vitro. Jap. J. Cancer Res. 81, 590-597 (1990)

82. Bøe, R., B. T. Gjertsen, O. K. Vintermyr, G. Houge, M. Lanotte \& S. O. Døskeland: The protein phosphatase inhibitor okadaic acid induces morphological changes typical of apoptosis in mammalian cells. Exp. Cell Res. 195, 237-246 (1991)

83. Arendt, T., M. Holzer, R. Fruth, M. K. Bruckner \& U. Gartner: Phosphorylation of tau, Abeta-formation, and apoptosis after in vivo inhibition of PP-1 and PP-2A. Neurobiol. Aging 19, 3-13 (1998)

84. Tergau, F., J. Weichert, I. Quentin, R. Opitz, C. von Zezschwits, J. Marwitz, V. Ritz \& H. J. Steinfelder: Inhibitors of ser/thr phosphatases 1 and 2A induce apoptosis in pituitary GH3. Naunyn Schmiedeberg's Arch. Pharmacol. 356, 8-16 (1997)

85. Weller, M., U. Malipiero, P. Groscurth \& A. Fontana: T cell apoptosis induced by interleukin-2 deprivation or transforming growth factor-beta 2: modulation by the phosphatase inhibitors okadaic acid and calyculin A. Exp. Cell Res. 221, 395-403 (1995)

86. Yan, Y., J. W. Shay, W. E. Wright \& M. C. Mumby: Inhibition of protein phosphatase activity induces p53dependent apoptosis in the absence of p53 transactivation. J. Biol. Chem. 272, 15220-15226 (1997)

87. Sheikh, M. S., X. Li, J. Chen, Z. Shao, J. V. Ordonez \& J. A. Foutana: Mechanisms of regulation of WAF1/CIP1 gene expression in human breast carcinoma: role of $\mathrm{p} 53$ dependent and independent signal transduction pathways. Oncogene 9, 3407-3415 (1994)

88. Davis, M. A., S. H. Chang \& B. F. Trump: Differential sensitivity of normal and H-ras oncogene-transformed rat kidney epithelial cells to okadaic acid-induced apoptosis. Toxicol. Appl. Pharmacol. 141, 93-101 (1996)

89. Kiguchi, K., D. Glesne, C. H. Chubb, H. Fujiki \& E. Huberman: Differential induction of apoptosis in human breast tumor cells by okadaic acid and related inhibitors of protein phosphatases 1 and 2A. Cell Growth Diff. 5, 9951004 (1994)

90. Sugarman, J. L., A. R. Thompson, R. Scavetta, C. K. Glass \& A. H. Schönthal: Differential effects of two types of tumor promoters, okadaic acid and 12-O-tetradecanoylphorbol-13-acetate, on growth and differentiation of human myeloid leukemia cells. Mol. Cell. Diff. 3, 51-71 (1995)

91. Morana, S. J., C. M. Wolf, J. Li, J. E. Reynolds, M. K. Brown \& A. Eastman: The involvement of protein phosphatases in the activation of ICE/CED-3 protease, 
intracellular acidification, DNA digestion, and apoptosis. $J$. Biol. Chem. 271, 18263-18271 (1996)

92. Kim, T. A., B. R. Velasquez \& C. E. Wenner: Okadaic acid regulation of the retinoblastoma gene product is correlated with the inhibition of growth factor-induced cell proliferation in mouse fibroblasts. Proc. Nat. Acad. Sci. USA 90, 5460-5463 (1993)

93. Schönthal, A. H. \& J. R. Feramisco: Inhibition of histone H1 kinase expression, retinoblastoma protein phosphorylation, and cell proliferation by the phosphatase inhibitor okadaic acid. Oncogene 8, 433-441 (1993)

94. Yatsunami, J., A. Komori, T. Ohta, M. Suganuma \& H. Fujiki: Hyperphosphorylation of retinoblastoma protein and p53 by okadaic acid, a tumor promoter. Cancer Res. 53, 239-241 (1993)

95. Felzien, L. K., M. G. Branden \& S. H. Benedict: Early phosphorylation of the retinoblastoma gene product regulates protein binding to the c-fos retinoblastoma control element during T cell activation. Mol. Immunol. 34, 507-517 (1997)

96. Rivedal, E., S.-O. Mikalsen \& T. Sanner: The nonphorbol ester tumor promoter okadaic acid does not promote morphological transformation or inhibit junctional communication in hamster embryo cells. Biochem.Biophys. Res. Comm. 167, 1302-1308 (1990)

97. Mordan, L. J., N. M. Dean, R. E. Honkanen \& A. L. Boynton: Okadaic acid: a reversible inhibitor of neoplastic transformation of mouse fibroblasts. Cancer Comm. 2, 237241 (1990)

98. Afshari, C. A. \& J. C. Barrett: Disruption of G0-G1 arrest in quiescent and senescent cells treated with phosphatase inhibitors. Cancer Res. 54, 2317-2321 (1994)

99. Lazzereschi, D., A. Coppa, G. Minicione, M. Lavitrano, F. Fragomele \& G. Colletta: The phosphatase inhibitor okadaic acid stimulates the TSH-induced G1-S phase transition in thyroid cells. Exp. Cell Res. 234, 425-433 (1997)

100. Pallas, D. C., L. K. Shahrik, B. L. Martin, S. Jaspers, T. B. Miller, D. L. Brautigan \& T. M. Roberts: Polyoma small and middle $\mathrm{T}$ antigens and SV40 small $\mathrm{t}$ antigen form stable complexes with protein phosphatase 2A. Cell 60, 167-176 (1990)

101. Kleinberger, T. \& T. Shenk: Adenovirus E4orf4 protein binds to protein phosphatase $2 \mathrm{~A}$ and the complex down regulates E1A-enhanced junB transcription. J.Virol. 67, 7556-7560 (1993)

102. Nishio, K., Y. Sugimoto, K. Nakagawa, S. Niimi, Y. Fujiwara, M. Bungo, K. Kasahara, H. Fujiki \& N. Saijo: Cross-resistance to tumor promoters in human cancer cell lines resistant to adriamycin or cisplatin. Brit. J. Cancer 62, 415-419 (1990)

103. Nishio, K., Y. Sugimoto, K. Kasahara, Y. Fujiwara, S. Nishiwaki, H. Fujiki, M. Ohata \& N. Saijo: Increased phophorylation of nuclear phosphoproteins in human lung- cancer cells resistant to cis-diamminedichloroplatinum (II). Int. J. Cancer 50, 438-442 (1992)

104. Saijo, N., K. Nishio, Y. Takeda, H. Arioka, T. Ishida, T. Nomoto, K. Fukuoka, H. Kurokawa \& H. Fukumoto: Phorbol ester and okadaic acid-resistant cells: The crossroads of signal transduction and drug resistance. Am. J. Med. 99 (suppl. 6A), 35S-39S (1995)

105. Wang, S.-J., R. Scavetta, H.-J. Lenz, K. Danenberg, P. V. Danenberg \& A. H. Schönthal: Gene amplification and multidrug resistance induced by the phosphatase-inhibitory tumor promoter, okadaic acid. Carcinogenesis 16, 637-641 (1995)

106. Zheng, B., T. C. Chambers, R. L. Raynor, P. N. Markham, H. M. Gebel, W. R. Vogler \& J. F. Kuo: Human leukemia K562 cell mutant (K562/OA200) selected for resistance to okadaic acid (protein phosphatase inhibitor) lacks protein kinase $\mathrm{C}$-, exhibits multidrug resistance phenotype, and expresses drug pump P-glycoprotein. $J$. Biol. Chem. 269, 12332-12338 (1994)

107. Takeda, Y., K. Nishio, N. Kubota, K. Miura, T. Morikage, T. Ohmori, S. Kudoh, H. Niitani \& N. Saijo: Establishment of a human small-cell lung-cancer subline resistant to okadaic acid. Int. J.Cancer 58, 882-890 (1994)

108. Ritz, V., J. Marwitz, E. Richter, C. Ziemann, I. Quentin \& H. J. Steinfelder: Characterization of two pituitary GH3 cell sublines partially resistant to apoptosis induction by okadaic acid. Biochem. Pharmacol. 54, 967-971 (1997)

109. Chambers, T. C., B. Zheng \& J. F. Kuo: Regulation by phorbol ester and protein kinase $\mathrm{C}$ inhibitors, and by a protein phosphatase inhibitor (okadaic acid), of Pglycoprotein phosphorylation and relationship to drug accumulation in multidrug-resistant human KB cells. Mol. Pharmacol. 41, 1008-1015 (1992)

110. Tohda, H., M. Takao, A. Kikuchi, T. Yasumoto \& A. Yasui: Unstable expression of the multi-drug-resistant phenotype in Chinese hamster ovary cells resistant to okadaic acid. Biochem.Biophys. Res. Comm. 232, 398-402 (1997)

111. Shima, H., H. Tohda, S. Aonuma, M. Nakayasu, A. A. Depaoli-Roach, T. Sugimura \& M. Nagao: Characterization of the PP2A alpha gene mutation in okadaic acid-resistant variants of CHO-K1 cells. Proc. Nat. Acad. Sci. USA 91, 9267-9271 (1994)

112. Kaneko, S., H. Shima, T. Amagasa, M. Takagi, T. Sugimura \& M. Nagao: Analysis by in vitro mutagenesis of PP2A okadaic acid responsive sequences. Biochem.Biophys. Res. Comm. 214, 518-523 (1995)

113. Aonuma, S., T. Ushijima, M. Nakayasu, H. Shima, T. Sugimura \& M. Nagao: Mutation induction by okadaic acid, a protein phosphatase inhibitor, in CHL cells, but not in S. typhimurium. Mutation Res. 250, 375-381 (1991)

114. Tohda, H., M. Nagao, T. Sugimura \& A. Oikawa: Okadaic acid, a protein phosphatase inhibitor, induces 
sister-chromatid exchanges depending on the presence of bromodeoxyuridine. Mutation Res. 289, 275-280 (1993)

115. Kuwabara, K., S. Odani, Y. Takahashi, M. Arakawa, N. Takagi, M. Nagao \& R. Kominami: Induction of karyotype instability in a murine tumor cell line by quercetin, 2-amino-1-methyl-6 phenylimidazo[4,5-b]pyridine, and okadaic acid, as revealed by transmission distortion of the inactive X chromosome. Mol. Carcinogenesis 14, 299-305 (1995)

116. Nakagama, H., S. Kaneko, H. Shima, H. Inamori, H. Fukuda, R. Kominami, T. Sugimura \& M. Nagao: Induction of minisatellite mutation in NIH 3T3 cells by treatment with the tumor promoter okadaic acid. Proc. Nat. Acad. Sci. USA 94, 10813-10816 (1997)

117. Van den Berg, S., A. Schönthal, A. Felder, B. Kaina, P. Herrlich \& H. Ponta: Antisense Fos oligodeoxyribonucleotides suppress the generation of chromosomal aberrations. In: E. Wickstrom (ed.) Prospects for Antisense Nucleic Acid Therapy of Cancer and Viral Infections, pp. 63-70. New York, N.Y.: Wiley-Liss Inc. (1991)

118. van den Berg, S., B. Kaina, H. J. Rahmsdorf, H. Ponta \& P. Herrlich: Involvement of fos in spontaneous and ultraviolet light-induced genetic changes. Mol. Carcinogenesis 4, 460-466 (1991)

119. van den Berg, S., H. J. Rahmsdorf, P. Herrlich \& B. Kaina: Overexpression of c-fos increases recombination frequency in human osteosarcoma cells. Carcinogenesis 14, 925-928 (1993)

120. Alberts, A. S. \& A. Schönthal: Positive and negative regulation of cell cycle progression by serine/threonine protein phosphatases. In: V. W. Hu (ed.) The Cell Cycle: Regulators, Targets, and Clinical Applications. New York: Plenum Press (1994)

121. Alberts, A. S., T. Deng, A. Lin, J. L. Meinkoth, A. Schönthal, M. C. Mumby, M. Karin \& J. R. Feramisco: Protein phosphatase $2 \mathrm{~A}$ potentiates activity of promoters containing AP-1 binding elements. Mol. Cell. Biol. 13, 2104-2112 (1993)

122. Yang, S.-I., R. L. Lickteig, R. Estes, K. Rundell, G. Walter \& M. C. Mumby: Control of protein phosphatase 2A by Simian virus 40 small-t antigen. Mol. Cell. Biol. 11, 1988-1995 (1991)

123. Frost, J. A., A. S. Alberts, E. Sontag, K. Guan, M. C. Mumby \& J. R. Feramisco: Simian virus 40 small $t$ antigen cooperates with mitogen-activated kinases to stimulate AP-1 activity. Mol Cell Biol 14, 6244-52 (1994)

124. Wadzinski, B. E., B. J. Eisfelder, L. F. Peruski, M. C. Mumby \& G. L. Johnson: NH2-terminal modification of the phosphatase 2A catalytic subunit allows functional expression in mammalian cells. J. Biol. Chem. 267, 1688316888 (1992)
125. Baharians, Z. \& A. H. Schönthal: Autoregulation of protein phosphatase type $2 \mathrm{~A}$ expression. J. Biol. Chem. 273, 19019-19024 (1998)

126. Kinoshita, N., H. Ohkura \& M. Yanagida: Distinct, essential roles of type 1 and $2 \mathrm{~A}$ protein phosphatases in the control of fission yeast cell division cycle. Cell 63, 405-515 (1990)

127. Ruediger, R., J. E. Van Wart Hood, M. Mumby \& G. Walter: Constant Expression and Activity of Protein Phosphatase 2A in Synchronized Cells. Mol. Cell. Biol. 11, 4282-4285 (1991)

128. Virshup, D. M., M. G. Kauffman \& T. J. Kelly: Activation of SV40 DNA replication in vitro by cellular protein phosphatase 2A. EMBO J. 8, 3891-3898 (1989)

129. Kikuchi, K., K. Kitamura, Y. Kakinoki, K. Nakamura, S.-i. Matsuzawa, M. Saadat \& Y. Mizuno: Gene expressions and activities of protein phosphatases $1 \alpha, 2 \mathrm{~A}$ and $2 \mathrm{C}$ in hepatocarcinogenesis and regeneration after partial hepatectomy. Cancer Detect. Prevent. 21, 36-43 (1997)

130. Nakamura, K., T. Koda, M. Kakinuma, S.-i. Matsuzawa, K. Kitamura, Y. Mizuno \& K. Kikuchi: Cell cycle dependent gene expression and activities of protein phosphatases PP1 and PP2A in mouse NIH3T3 fibroblasts. Biochem. Biophys. Res. Comm. 187, 507-514 (1992)

131. Kakinoki, Y., K. Kitamura, S. Matsuzawa, Y. Mizuno, T. Miyazaki \& K. Kikuchi: Gene expression and activities of protein phosphatases PP1 and PP2A in rat liver regeneration after partial hepatectomy. Biochem.Biophys. Res. Comm. 185, 291-297 (1992)

132. Kam, E., W. Nirunsuksiri, B. Hager, P. Fleckman \& B. A. Dale: Protein phosphatase activity in human keratinocytes cultured from normal epidermis and epidermis for patients with harlequin ichthyosis. Br. J. Dermatol. 137, 874-882 (1997)

133. Fernandez, A., D. L. Brautigan, M. Mumby \& N. J. C. Lamb: Protein phosphatase type-1, but not type-2A, modulates actin microfilament integrity and myosin light chain phosphorylation in living nonmuscle cells. J. Cell Biol. 111, 103-112 (1990)

134. Wera, S., A. Fernandez, N. J. Lamb, P. Turowski, M. Hemmings-Mieszczak, R. E. Mayer-Jaekel \& B. A. Hemmings: Deregulation of translational control of the 65$\mathrm{kDa}$ regulatory subunit (PR65 alpha) of protein phosphatase 2A leads to multinucleated cells. J. Biol. Chem. 8, 2137421381 (1995)

135. Hagiwara, M., A. Alberts, P. Brindle, J. Meinkoth, J. Feramisco, T. Deng, M. Karin, S. Shenolikar \& M. Montminy: Transcriptional attenuation following cAMP induction requires PP-1-mediated dephosphorylation of CREB. Cell 70, 105-113 (1992)

136. Alberts, A. S., M. Montminy, S. Shenolikar \& J. R. Feramisco: Expression of a peptide inhibitor of protein phosphatase 1 increases phosphorylation and activity of 
CREB in NIH3T3 fibroblasts. Mol. Cell. Biol. 14, 43984407 (1994)

137. Ruediger, R., N. Brewis, K. Ohst \& G. Walter: Increasing the ratio of PP2A core enzyme to holoenzyme inhibits Tat-stimulated HIV-1 transcription and virus production. Virology 238, 432-443 (1997)

138. Westphal, R. S., K. A. Anderson, A. R. Means \& B. E. Wadzinski: A signaling complex of $\mathrm{Ca}^{2+}$-calmodulindependent protein kinase IV and protein phosphatase 2A. Science 280, 1258-1261 (1998)

139. Hériché, J.-K., F. Lebrin, T. Rabilloud, D. Leroy, E. M. Chambaz \& Y. Goldberg: Regulation of protein phosphatase $2 \mathrm{~A}$ by direct interaction with casein kinase $2 \alpha$. Science 276, 952-955 (1997)

140. Murata, K., J. Wu \& D. L. Brautigan: B cell receptorassociated protein alpha4 displays rapamycin-sensitive binding directly to the catalytic subunit of protein phosphatase 2A. Proc. Natl. Acad.Sci. USA 94, 1062410629 (1997)

141. Pitcher, J. A., E. S. Payne, C. Csortos, A. A. DePaoliRoach \& R. J. Lefkowitz: The G-protein-coupled receptor phosphatase: a protein phosphatase type $2 \mathrm{~A}$ with a distinct subcellular distribution and substrate specificity. Proc. Natl. Acad.Sci. USA 92, 8343-8347 (1995)

142. Adler, H. T., F. S. Nallaseth, G. Walter \& D. C. Tkachuk: HRX leukemic fusion proteins form a heterocomplex with the leukemia-associated protein SET and protein phosphatase 2A. J. Biol. Chem. 272, 2840728414 (1997)

143. Kawabe, T., A. J. Muslin \& S. J. Korsmeyer: HOX11 interacts with protein phosphatases PP2A and PP1 and disrupts a G2/M cell-cycle checkpoint. Nature 385, 454-458 (1997)

144. Andjelkovic, N., S. Zolnierowicz, C. Van Hoof, J. Goris \& B. A. Hemmings: The catalytic subunit of protein phosphatase $2 \mathrm{~A}$ associates with the translation termination factor eRF1. EMBO J. 15, 7156-7167 (1996)

145. Okamoto, K., C. Kamibayashi, M. Serrano, C. Prives, M. C. Mumby \& D. Beach: p53-dependent association between cyclin $\mathrm{G}$ and the B' subunit of protein phosphatase 2A. Mol. Cell. Biol. 16, 6593-6602 (1996)

Key Words: Phosphatases; PP2A, Phosphatase Inhibitors, Okadaic Acid, Signal Transduction.

Send correspondence to: Dr Axel H. Schönthal, Department of Molecular Microbiology and Immunology, K. Norris Jr. Comprehensive Cancer Center, University of Southern California, 2011 Zonal Ave., HMR-405, Los Angeles, CA. 90033, Tel:323-442-1730, Fax: (323)-442-1721, E-mail: schontha@hsc.usc.edu 